\title{
Expert System for Simulation of Pest and Disease Diagnosis in Onion Plant Using Putty Shafer Method and Rule-Based Approach
}

\author{
Melia Dianingrum ${ }^{\mathrm{a}, 1, *}$, Nandang Hermanto ${ }^{\mathrm{b}, 2}$, Mohamad Iqbal Rifa'i ${ }^{\mathrm{b}, 3}$ \\ ${ }^{a}$ Information System Program, STMIK AMIKOM Purwokerto, Central Java, Indonesia \\ ${ }^{\mathrm{b}}$ Informatics Engineering Program, STMIK AMIKOM Purwokerto, Central Java, Indonesia \\ ${ }^{1}$ meliadianingrum@amikompurwokerto ac.id; ${ }^{2}$ nandanghermanto@ amikompurwokerto.ac.id; ${ }^{3}$ Iqbalrifai.mohamad27@gmail.com \\ * corresponding author
}

\begin{abstract}
The expert system is trying to adopt a system of human knowledge into a computer so that the computer can solve problems like the experts. The expert system is well designed in order to solve a particular problem by mimicking the work of the expert. The development of an expert system is expected to be resolved problems with the help of experts. The problems addressed by an expert not only the problems that rely on algorithms but sometimes elusive problems. An expert with knowledge and experience can overcome these problems. The application of an expert system in this study is made to diagnose pests and diseases in onion plants based on the web. The Data Collection method used is literature studies, interviews and observation. The stages of research used are literature review, data processing analyst, and Onion analyzed and photographed which then is uploaded and analyzed, Dempster Shafer method, application development, evaluation. In the last stage is the pilot study conducted using a Blackbox method and testing to the user. The result of the research is in the form of an expert system application that can diagnose pests and diseases of onion as many as 7 types of diseases. The output system is in the form of onion disease searching result obtained based on the symptoms inputted by the user. The result of Blackbox Testing is all functions of the application successfully run well. Testing to the users rated well both appearance and information of the application.
\end{abstract}

Keywords: expert system; Putty Shafer; shallot; Blackbox

\section{Introduction}

Brebes is the center of the largest red onion producer in Indonesia, supplying about $75 \%$ of onion needs in Central Java province and 23\% of national needs. With production as much as 312,533, 2 tons in 2009, the red Onion farm accounted for the PDRB regency of Brebes by 58\%. Some of the varieties of onions developed in the Brebes Regency are Varieties of Bima Brebes, Kuning, Timor, Sumenep, and imported onion varieties such as from the Philippines and Bangkok (especially planted in the dry season only). The onions in Brebes are planted with monoculture or intercropping systems, with the harvest time in May-June and August-September. Some essential climatic factors in the cultivation of onions are the altitude of the place, temperature, light, rainfall, and wind. Onion for Brebes is a flagship product considering its position as the largest producer of the commodity at the national level as well as having a distinctive brand suitable for the onion consumers in Indonesia. Brebes onions are famous for the better quality of onions originating from other regions in Indonesia or abroad, such as Thailand and China. The original onion Brebes has a great taste, which is more pungent and fragrant, and the finished product (fried onion) is more delicious and savory.

Onion is one of the flagship products and flagship industry sector Brebes Regency. This is affirmed in the regional regulation of Brebes number 8 the year 1986 that the regional emblem in the form of egg round, as well as pictures of onions, symbolize that salted egg and onion are the specific results of Brebes area [1][2]. Especially in the area of the district of Jatibarang, almost the majority of the community residents are farming by farming, relying on the available land. Increased production constraints will be increasingly complex due to global climate change eliciting new pests and diseases that cause unstable production. The average farmer spent a fifth of his energy to eradicate pests and diseases in the onion. Farmers should work hard because of the effects of the attack. Therefore, it takes the role of an expert or expert to accompany the farmer in diagnosing the pest and disease of onions, which not only knows the pests and diseases that have occurred but what will happen. So here the role of Kebonagung Agricultural Counseling Center, Jatibarang District, Brebes is a government agency that has the determination of solutions and accuracy of pest and 
disease handling information. To minimize the occurrence of damage to the onion plants from pests and diseases of the onion.

From the data extracted from the Kebonagung Agricultural Counseling Center, Jatibarang District, Brebes for the widespread attack of one of the pests of onions seen in table 1 follows:

Table 1 Data Of Disease Name In Onions

(Source: Kebonagung Agricultural Counseling Center, Jatibarang District, Brebes)

\begin{tabular}{|c|l|c|c|c|c|c|}
\hline No & Location (village) & Spacious & Unit area & Pest Attack Area & Percentage & Number of cases \\
\hline 1 & Rengasbandung & 350 & $\mathrm{Ha}$ & 10 & $10.0 \%$ & 100 \\
\hline 2 & Kedungtukang & 350 & $\mathrm{Ha}$ & 12 & $12.0 \%$ & 144 \\
\hline 3 & Kendawa & 350 & $\mathrm{Ha}$ & 8 & $8 \%$ & 64 \\
\hline 4 & Tembelang & 350 & $\mathrm{Ha}$ & 6 & $6 \%$ & 36 \\
\hline
\end{tabular}

Based on the data above, Jatibarang Sub-district is the most widespread and most cases for the Spread of one of the pests of Onion Caterpillars (Spodoptera Exigua), Trotol disease, purple blotch, leaf-cutter flies (Liriomyza sp). On the onion plant. Therefore, it takes more attention from experts who are in the Kebonagung Agricultural Counseling Center that covers the four villages to help experts in diagnosing pests and diseases of onions.

\section{Literature Review}

\subsection{Expert System}

The expert system is a system that seeks to adopt human knowledge to the computer so that the computer can solve the problem as usual by experts. The basic idea of an expert system applied artificial intelligence technology, is simple. Expertise is transferred from an expert to a computer. This Knowledge is then stored on the computer, and users run the computer for the specific advice required. The expert system asks for facts and can make inferences up to a definite conclusion. Knowledge in the expert system may be an expert or knowledge generally found in books, journals, websites and people with knowledge of a field. A good expert system is designed to solve a particular problem by emulating the work of the experts [3][4][5].

\subsection{Dempster Shafer}

Dempster Shafer is a mathematical theory for proving based on belief functions and plausible reasoning (sensible thinking). It used to combine separate pieces of information (evidence) to calculate the likelihood of an event. This theory was developed by Arthur P Dempster and Glenn Shafer [6][7][8].

There is a wide range of reasoning with a complete and very consistent model, but many problems can not be resolved entirely and consistently. Such inconsistency is due to the addition of new facts. Such reasoning is called a nonmonotonical study. To overcome that inconsistency, then we can use the theory of Putty Shafer. In a narrow sense, the definition of the theory of Putty Shafer is referring to the original conception of the theory by the Shafer Putty. However, it is a theory commonly used to define reason more broadly than some similar conventional approaches, as has been adapted for certain types of situations. In certain situations, many authors have offered different rules to combine the evidence, usually by looking back at it and handling the evidence conflict better[9][10].

In general, the Dempster-Shafer theory is written in an interval:

\section{[Belief, Plausibility]}

Belief (Bel) is the measure of the power of evidence (evidence) in favor of a set of propositions. If it is 0 , it indicates that there is no evidence, and if it is worth 1 indicates any certainty or plausibility (P1).

$$
P l(s)=1-B e l(\ulcorner s)
$$

Plausibility also HCV 0 to 1 . If sure it will be $\neg S$, then it can be said that the Bel $=(\neg S)=0$. The theory of Putty Shafer is known for its frame of discernment, which is associated with $\Theta$. This Frame is the talking universe of a group of hypotheses So it is often referred to as the environment. The goal is to associate the confidence size of $\theta$ elements. Not 
Melia Dianingrum, Nandang Hermanto, M Iqbal Rifa'i / Vo1. 2, No. 1, March 2019, pp. 1-8

all of the evidence directly supports each element. Therefore, there needs to be a probability of density function (m). The $\mathrm{M}$ value not only defines $\theta$-only elements but also all of its subsets. So if $\theta$ contains $n$ elements, then a subset of $\theta$ is $2 \mathrm{n}$. The sum of all $\mathrm{m}$ in a subset of $\theta$ equals 1 . If there is no information to select a hypothesis, then the value:

$$
m\{\Theta\}=1.0
$$

If it is known $\mathrm{X}$ is a subset of $\theta$, with $\mathrm{M} 1$ as its density function, and $\mathrm{Y}$ is also a subset of $\theta$ with $\mathrm{M} 2$ as its density function, it can be formed a combination function of M1 and M2 as M3, namely:

$$
\mathrm{m}_{3}(\mathrm{Z})=\frac{\sum \mathrm{X} \cap \mathrm{Y}=\mathrm{Z} \mathrm{m}_{1}(\mathrm{X}) \cdot \mathrm{m}_{2}(\mathrm{Y})}{\sum \mathrm{X} \cap \mathrm{Y}=\varnothing \mathrm{m}_{1}(\mathrm{X}) \cdot \mathrm{m}_{2}(\mathrm{Y})}
$$

\subsection{Rule-Based Approaches}

Rule-based approaches in this expert system using rule-Base Reasoning method, a method of the approach using the if-then pattern can be used in the process of being diagnosed against the pests and diseases of horticultural crops which has contained several expert knowledge in a problem and an expert with its performance can solve the problem sequentially[11][12]. With the approach method, The resulting rules can be rereviewed by an expert to be repaired or modified to obtain results better [13].

\section{Research Methods}

\subsection{Data Collection}

The steps used to obtain the data are as follows:

a. Interview

According to [14], interviews are two-way communication to get data from respondents. It is the most widely used acquisition method. This method involves talking with an expert directly in an interview. This interview aims at collecting data directly from experts/experts.

b. Observation

According to [15], observation is a technique or approach for obtaining primary data by observing the data objects directly.

c. Literature study

The library method is a technique of data collection and resources such as books, documents, publications, or the internet [16].

\subsection{System Development}

When implementing the development model using the waterfall model. In the book Software Engineering [17], mention that one of the SDLC system development is by waterfall model.

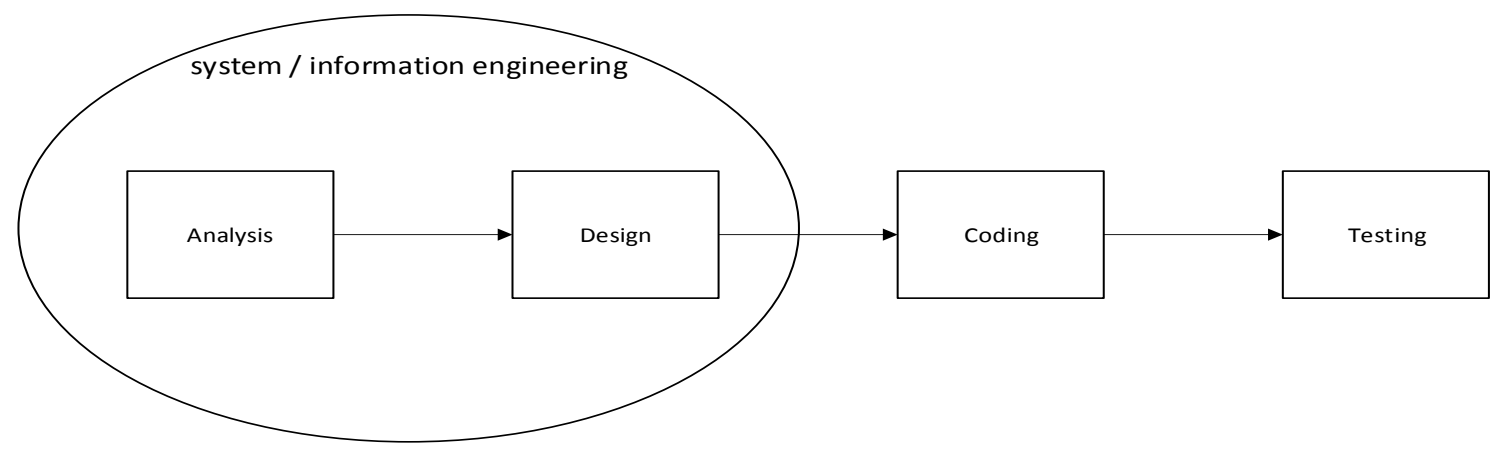

Fig. 1 Illustration of The Waterfall Model 
Melia Dianingrum, Nandang Hermanto, M Iqbal Rifa'i / Vo1. 2, No. 1, March 2019, pp. 1-8

\subsection{Testing}

Testing applications performed by developers using the Black Box Testing method. Black Box Testing is testing software in terms of functional specifications without testing the design and code of the program [17] [18].

\section{Discussion}

\subsection{Results and Discussion}

A system of diagnosis of pests and diseases in the red onion plant is one of the solutions used to process the diagnosis of pests and diseases of onions based on the website is one of the breakthroughs in the technological world where the onion farmers can identify pests and diseases of onion plants through an accessible application on the Internet to find out pests and diseases that are attacking the onion plant.

In this study, the method used is the method of Dempster Shafer, where it can determine the process of diagnosing pests and diseases of the onions that are inferred from the symptoms posed by the red onion plant destruction organisms. Of the seven pest and disease data, 29 symptoms are obtained in determining the diagnosis result of pest and diseases of onions include:

a. Pest and disease Data

Table 2 List of Pests And Diseases

\begin{tabular}{|c|c|}
\hline Disease Code & Name of illness \\
\hline HP1 & Onion caterpillars \\
\hline HP2 & Dead Shoots \\
\hline HP3 & Moler \\
\hline HP4 & Automatic \\
\hline HP5 & Trotol \\
\hline HP6 & Leaf-Cutter Flies \\
\hline HP7 & Leaf Spot \\
\hline
\end{tabular}

b. Symptom Data

Table 3 Symptoms List

\begin{tabular}{|c|l|}
\hline Symptom code & \multicolumn{1}{|c|}{ Symptom name } \\
\hline G01 & Tip of the leaves appear perforated \\
\hline G02 & The leaves look translucent \\
\hline G03 & White leaf Patches \\
\hline G04 & Leaves hang down/wither \\
\hline G05 & Rotten leaf tip wet \\
\hline G06 & Leaf Tip Brown \\
\hline G07 & The tip of dead leaves \\
\hline G08 & Leaves twisted \\
\hline G09 & Yellow leaf \\
\hline G10 & Leaves hang down/wither \\
\hline G11 & Rotting roots \\
\hline G12 & The root of the tuber is whitish boletus \\
\hline G13 & The root of the watery tuber \\
\hline G14 & White leaf Patches \\
\hline G15 & Leaf patches widen and become greenish \\
\hline G16 & Sudden death plants \\
\hline G17 & Leaf Bottom Fall \\
\hline G18 & The base of the leaf shrinks \\
\hline G19 & Leaves are bent spots \\
\hline
\end{tabular}


Melia Dianingrum, Nandang Hermanto, M Iqbal Rifa'i / Vol. 2, No. 1, March 2019, pp. 1-8

\begin{tabular}{|l|l|}
\hline G20 & White or gray leaf patches \\
\hline G21 & Edge and dry \\
\hline G22 & Tuber rot \\
\hline G23 & There are white spots on the leaves \\
\hline G24 & Leaves become dry \\
\hline G25 & Leaf color as burned \\
\hline G26 & Round and elongated leaf patches \\
\hline G27 & Brown leaf spotting with yellow edges \\
\hline G28 & The most number of spots on the leaf \\
\hline G29 & The tissue on dead leaf spotting \\
\hline
\end{tabular}

\section{c. Rule Creation}

In the manufacture of this inference machine based on Putty Method Shafer. This method of inference, withdrawal of conclusions based on the symptoms of pests and diseases in the red onion plant, with the rules of the production rule that has been made in the previous step. So formed the decision tree in Figure 2 as follows:

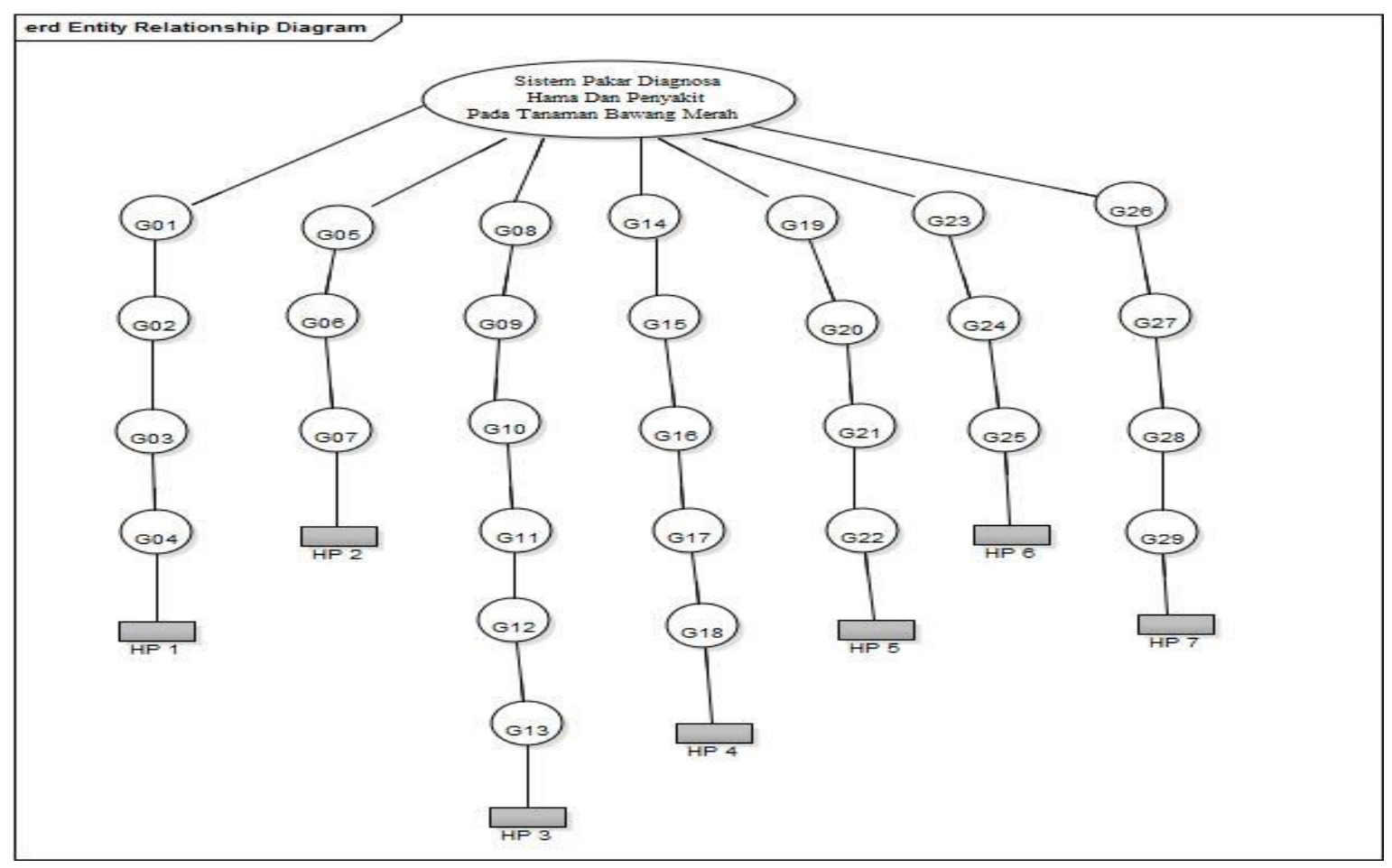

Fig. 2 Decision Tree

Figure 2 is the decision tree of the system of diagnosis of pests and diseases of the red onion plants, consisting of 7 pests and 29 symptoms in the plant of onions.

\section{d. Putty Shafer Value}

In the method of Putty Shafer then can be created a table of relation that contents about the relationship between disease and symptoms and the value of density (m) A symptom of the disease. Here is table 4 explaining the relationship between symptoms, illness and the value of density.

Table 4 Symptoms Relationship table, disease, and Density Value

\begin{tabular}{|l|l|l|l|l|l|l|l|l|}
\hline & P1 & P2 & P3 & P4 & P5 & P6 & P7 & Density Value \\
\hline G1 & $*$ & $*$ & & & & & & 0.4 \\
\hline G2 & $*$ & & & & & & & 0.8 \\
\hline
\end{tabular}


Me1ia Dianingrum, Nandang Hermanto, M Iqbal Rifa'i / Vol. 2, No. 1, March 2019, pp. 1-8

\begin{tabular}{|l|l|l|l|l|l|l|l|l|}
\hline & P1 & P2 & P3 & P4 & P5 & P6 & P7 & Density Value \\
\hline G3 & $*$ & & & & & & & 0.8 \\
\hline G4 & $*$ & $*$ & $*$ & & & & & 0.3 \\
\hline G5 & $*$ & & & & & & & 0.9 \\
\hline G6 & $*$ & $*$ & & & & & & 0.7 \\
\hline G7 & $*$ & & & & & & & 0.9 \\
\hline G8 & & $*$ & & & & & & 0.9 \\
\hline G9 & & $*$ & & & & & & 0.9 \\
\hline G10 & & $*$ & & & & & & 0.9 \\
\hline G11 & & & $*$ & $*$ & & & & 0.7 \\
\hline G12 & & & $*$ & $*$ & & & & 0.7 \\
\hline G13 & & & $*$ & & & $*$ & $*$ & 0.4 \\
\hline G14 & & & $*$ & & & & & 0.8 \\
\hline G15 & & & & $*$ & & & & 0.8 \\
\hline G16 & & & & $*$ & $*$ & $*$ & $*$ & 0.9 \\
\hline G17 & & & & & $*$ & & & 0.9 \\
\hline G18 & & & & & $*$ & & & 0.8 \\
\hline
\end{tabular}

In table 4 Displays the relationship or relationship of existing symptoms with the disease, as well as the value of density (m) of each symptom given by the expert and method of Putty Shafer does not regulate the symptoms, but the absolute from experts based on experience and theory of knowledge that is in the experts.

e. Application creation

After the diagnosis rules derived from the processing of disease data and symptoms, the next step is to perform the process of developing the system. At this stage, the development of the system used is SDLC using the waterfall Model as its implementation model.

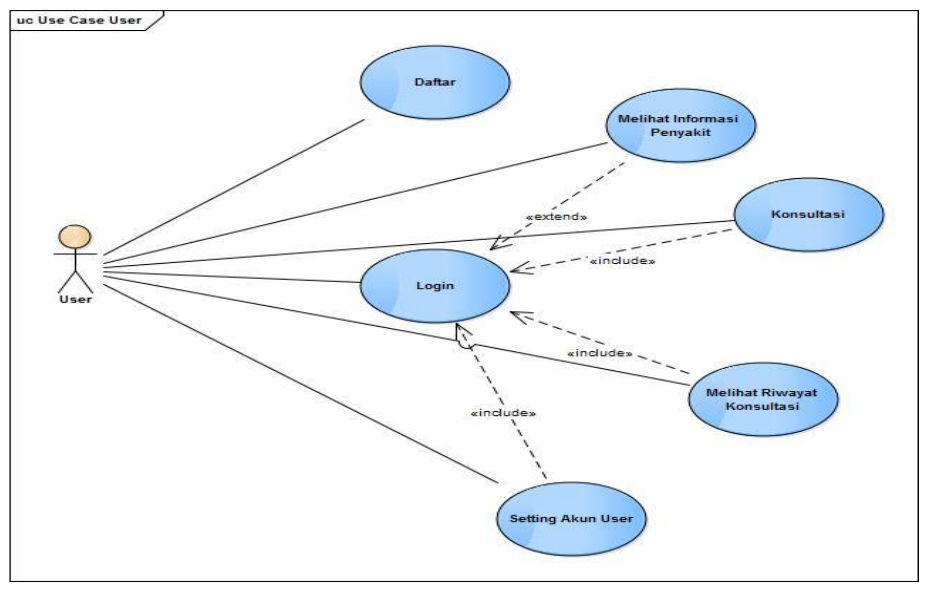

Fig. 3 Use Case Diagram User

Here is the definition of use case user admin in the figure 3 use case Diagram user.

Table 5 Definition of Use Case User

\begin{tabular}{|l|l|l|}
\hline No & \multicolumn{1}{|c|}{ Use Case } & \multicolumn{1}{c|}{ Description } \\
\hline 1 & Login & Process to perform user Login \\
\hline 2 & User account Settings & $\begin{array}{l}\text { User can change admin name also username and password used } \\
\text { to login }\end{array}$ \\
\hline
\end{tabular}


Melia Dianingrum, Nandang Hermanto, M Iqbal Rifa'i / Vol. 2, No. 1, March 2019, pp. 1-8

\begin{tabular}{|l|l|l|}
\hline No & \multicolumn{1}{|c|}{ Use Case } & \multicolumn{1}{c|}{ Description } \\
\hline 3 & View disease information & Process See User disease information \\
\hline 4 & Consultation & Consultation viewing process \\
\hline 5 & View your consultation history & Process of viewing consultation history \\
\hline 6 & List & Sign up to do the consultation \\
\hline
\end{tabular}

f. System implementation

\section{Login}

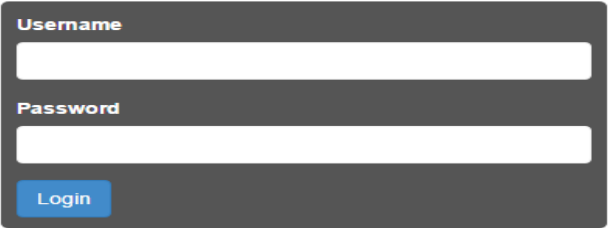

Figure 4 User Login page

Figure 4 explaining the user Login menu used to enter the user page, before accessing the next page, the user must log in by entering the username and Password. If the user enters an incorrect username, then the alert of your username appears incorrectly on the login page. Then if the user enters the correct username and password is wrong, it appears warning the user the wrong password.

\section{Conclusion}

From the results of research that has been done related to the expert system to diagnose pests and diseases of the onion, then it can be concluded, as follows:

a. The research has successfully built an expert system for simulated pest and disease diagnoses that include the onion plant using the Shafer Putty Method and rule-based approach.

b. The use of waterfall is beneficial in the process of creating an expert system because this model provides a flow of software approach in a sorted range from analysis, design, coding and testing.

c. Based on the results of testing using Blackbox The system of the pest diagnosis and disease of onion crops webbased has been under the design that has been set at the level of the system.

\section{References}

[1] S. Abbasbandy, B. Asady, Ranking of fuzzy numbers by sign distance, Information Sciences, 176(2006), 2405-2416.

[2] K. C. Chai, K. M. Tay, C. P. Lim, A new Dempster-Shafer theory-based method with fuzzy targets for fuzzy sets ranking, in Proceedings of IEEE Int'l Conference on Fuzzy Systems, Hyderabad, India, 2013.

[3] P. T. Chang, K. C. Hung, Applying the fuzzy-weighted-average approach to evaluate network security systems, Computers and Mathematics with Applications, 49(2005), 1797-1814.

[4] S. M. Chen, L. W. Lee, Fuzzy decision making based on likelihood-based comparison relations, IEEE Transaction on Fuzzy Systems, 18(2010), 613-628.

[5] L. Q. Dat, V. F. Yu, S.Y. Chou, An improved ranking method for fuzzy numbers based on the centroid-index, International Journal of Fuzzy Systems, 14(2012), 413-419.

[6] V. N. Huynh, Y. Nakamori, J. Lawry, A probability-based approach to comparison of fuzzy numbers and applications to target-oriented decision making, IEEE Transaction on Fuzzy Systems, 16(2008), 371-387.

[7] F. T. Lin, Fuzzy job-shop scheduling based on ranking level ( ) interval-valued fuzzy numbers, IEEE Transaction on Fuzzy Systems, 10(2002), 510-522. 
Melia Dianingrum, Nandang Hermanto, M Iqbal Rifa'i / Vo1. 2, No. 1, March 2019, pp. 1-8

[8] A. Martin, A. L. Jousselme, C. Osswald, Conflict measure for the discounting operation $n$ belief functions, in Proceeding of IEEE Int'l Conference on Information Fusion, 2008.

[9] C. K. Murphy, Combining belief functions when evidence conflicts, Decision Support Systems, 29(2000), 1-9.

[10] K. Sentz, S. Ferson, Combination of evidence in Demspter-Shafer Theory, Albuquerque, New Mexico: Sandia National Laboratories, 2002.

[11]P. Sevastianov, Numerical methods for interval and fuzzy number comparison based on the probabilistic approach and Dempster-Shafer theory, Information Sciences, 177(2007), 4645-4661.

[12] R Pratama, R Wahyudi, H Marcos, I Budiati, L N Khasanah, F Ichsan, and F P Wijaya. Expert system for diagnosing vertebrate animals with Visual Prolog 8.0. In 3rd International Conference on Information Technology, Information System and Electrical Engineering, pages 100-104, Nov 2018.P. Smets, Decision making in the TBM: the necessity of the pignistic transformation, International Journal of Approximate Reasoning, 38(2005), 133-147.

[13]F. Y. Vincent, H. T. X. Chi and C. W. Shen, Ranking fuzzy numbers based on epsilon-deviation degree, Applied Soft Computing, 13(2013), 3621-3627.

[14] Y. M. Wang, T. M. S. Elhag, Fuzzy TOPSIS method based on alpha level sets with an application to bridge risk assessment, Expert Systems with Applications, 31(2006), 309-319.

[15] K. Yamada, A new combination of evidence based on compromise. Fuzzy sets and Systems, 159(2008), 1689-1708.

[16] C. H. Yeh, H. Deng, A practical approach to fuzzy utilities comparison in fuzzy multicriteria analysis, International Journal of Approximate Reasoning, 35(2004), 179-194.

[17]F. Zhang, J. Ignatius, C.P. Lim, Y. Zhao, A new method for deriving priority weights by extracting consistent numericalvalued matrices from interval-valued fuzzy judgement matrix, Information Sciences, 279(2014), 280-300. 